\title{
Lung Obstructive Function Score 0
}

National Cancer Institute

\section{Source}

National Cancer Institute. Lung Obstructive Function Score O. NCI Thesaurus. Code C131055.

FEV1 greater than or equal to $80 \%$. 